\title{
The Genus Mastigosporium Riess in Finland
}

\author{
Kaiho Mäkelä
}

\author{
Department of Plant Pathology, University of Helsinki
}

\begin{abstract}
This paper is part of a larger study the fungi of the leaf-spot dieseases which affcet the grasses on leys in Finland. The material examined consisted of grasses growing on cultivated grassland or the borders of fields. The material (c. 3650 samples) was collected at Viik and the Muddusniemi Experiment Farm of Helsinki University, at Experiment Stations of the Agricultural Research Centre and in other localities in southern Finland. Collections of the Plant Pathology Department of Helsinki University have also been examined.

The species Mastigosporium album Riess, M. rubricosum (Dearn \& Barth.) Nannf., and M. deschampsiae Jørstad caused leaf-spot disease in certain grasses. The cleistothecium-like resting stage with inner spores was found in many localities in natural specimens of the species $M$. album and $M$. rubricosum.
\end{abstract}

Mastigosporium Riess is a genus of $\mathrm{Mo}$ niliales (AINSWORTh 1961). Four species have been described. These occur as parasites of grasses causing leaf-spot diseases. The genus is characterized by short conidiophores which emerge from the surface tissue of the plant, producing large, hyaline, septate conidia at their terminal ends. No perfect stage has been described for any of the species (SAcCardo 1886, Sprague 1938, Jørstad 1947, Bollard 1950).

\section{Materials and methods}

Studies on the genus Mastigosporium were carried out in 1966-69 at the Plant Pathology Department of Helsinki University, located at Viik, Helsinki. The material examined covered the diseases that attack grasses growing on leys and the borders of fields. The observations were made and the fungus samples collected during the period from spring thaw and the first real snowfall in autumn. In addition, samples were collected (c. 3650 samples) at the Muddusniemi Experiment Farm of Helsinki University in Inari, at the experiment stations of the Agricultural
Research Centre, in Hämeenlinna, Iitti, and the neighbouring localities of Helsinki (Fig. 1). The collections of the Plant Pathology Department of Helsinki University (HPP) were examined. Microscopic slides for measuring and drawing or photographing were prepared from all samples bearing spores of Mastigosporium. In the material, 97 samples came from Alopecurus pratensis, 2 from A.geniculatus, 271 from Dactylis glomerata, 86 from Phleum pratense, 27 from Agrostis tenuis, 21 from the species of Calamagrostis and 4 from Deschampsia caespitosa, the total number of samples being 546. Varying and representative materials were used for the size readings and colour descriptions of the disease symptoms. The colour descriptions were based on the classification by KORNERUP and WANSGHER (1967). Conidia produced in natural infestations were chiefly examined. They were usually more abundant than in artificial media, where Mastigosporium fungi grew slowly (cf. SPRAgue 1938, Bollard 1954, Austwick 1954).

For the present study, leys with the following grass species and varieties were established at Viik in 1966-68: 
Agrostis tenuis Sibth.

Alopecurus pratensis L.

Bromus inermis Leyss.

Dactylis glomerata L.

Festuca pratensis Huds.

F. rubra L.

Lolium multiflorum Lam.

L. perenne L.

Phleum pratense $\mathrm{L}$.

Poa pratensis $\mathrm{L}$.

The size of the field plots varied from 5 to $50 \mathrm{~m}^{2}$ in different years. The grasses were sown in rows $15 \mathrm{~cm}$ apart. Specimens were also collected from seed production experiments in which the grass species were Dactylis glomerata. Festuca pratensis, and Phleum pratense, all of them Tammisto varieties.

Inoculation studies on grasses were carried out under laboratory conditions. The grasses examined were grown in a greenhouse to a height of about $10-15 \mathrm{~cm}$. The plants were inoculated with a spore suspension prepared in distilled water with conidia produced on

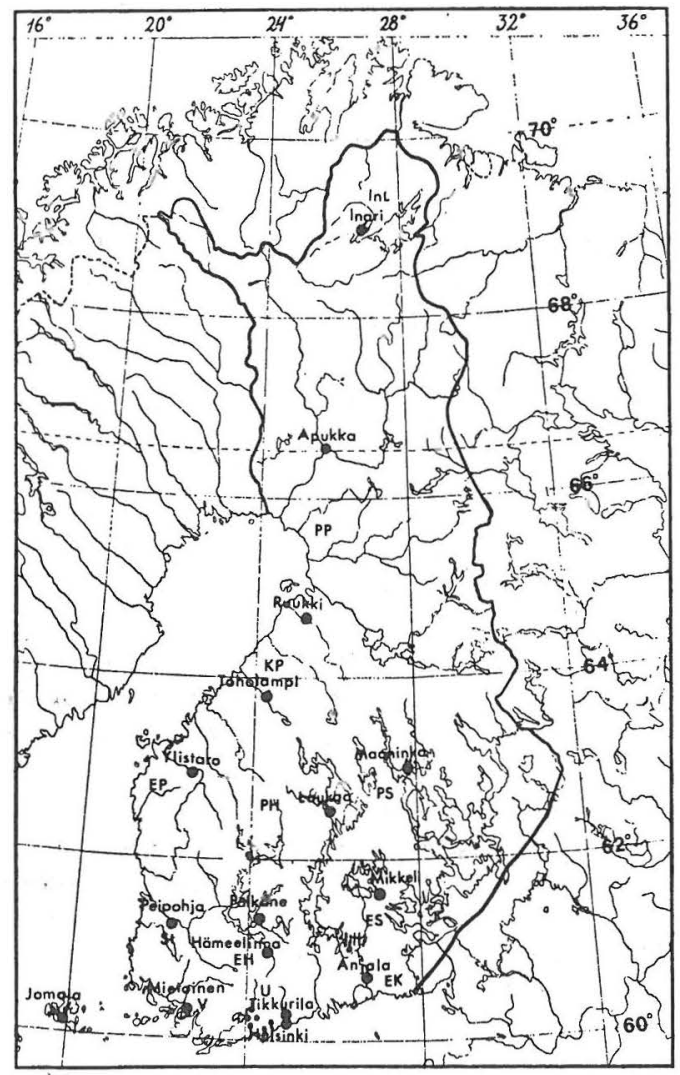

Fig. 1. Origin of the material.
Foreign

Finnish

Jokionen, Jo 266

Tammisto, Hera

Tammisto, Paavo, Leto

Dasas

Leda

Valinge

Tammisto, Tarmo

Ötofte

native leaves or with infected pieces of leaves which were attached to the leaf surface with moist cotton. In addition to the new sprouts, separate leaves of grasses placed in big Petri dishes on moist filter paper were also inoculated. After inoculation the plants were kept in the incubator at $10^{\circ} \mathrm{C}$ under illuminated and humid conditions (cf. Sprague 1938, Bollard 1950, Buhl \& Lange 1965). Fungus culturing in pure culture (Difco, $2 \%$ maltextract-, Difco, potato-dextrose-, and grassextract agar (cf. Sprague 1938, Bollard 1950) was also attempted.

\section{Results}

Mastigosporium album Riess

in Fresenius, Beitr. Mycol. 2: 56 (1852), (cf. Saccordo 4: 220 1886; Sprague 1938: 297). The species is locally common in Europe, particularly on Alopecurus pratensis L., e.g. in Denmark (Lind 1913), in Sweden (Lundell \& Nannfeldt 1939), in Norway, where it has also been recorded on A. geniculatus $L$. and A. ventricosus Pers. (Jørstad 1924, 1945), in Estonia (KASK, 1959, Sarv 1960, 1966), in Central Europe (Lindau 1907: 402), in Germany (Sorauer 1874: 354), also recorded on Dactylis glomerata L. (BuHL \& LANGE 1965) in Bohemia (BAudvš 1916) and in Great Britain (SAMPSON \& WESTERN 1942, Bollard 1950), where it was also recorded on Lolium perenne L. (LACEY 1967). In Canada the fungus was recorded for the first time in 1953 (Greelman 1956), in the USA in 1954 (Ross 1954).

In Finland Pohjakallio (1936) described the fungus as very abundant at Jokioinen in 1935, Rainio (1936) also regards it as being common. Rainio claims to have proved by experiments with both cultures and inoculations that $M$. album and Dilophospora graminis Desm. are two conidial stages of the ascomycete Dilophia graminis (Fuck.) Sacc. Fuckel (1869, of. Lindau 1907: 402) holds the same view, while Schafrnit and Wirben (1928) regard M. album and Dilophia graminis 
M. album

on Alopecurus pratensis

HEISINKI

HÄMEGENL INRA

M. rubricosum

on Doctylis glomerata

HELSINKI

HÄMEENLINNA

on Phleum pratense

HED, SINKKI

HÄMEENL TNNA

INARI
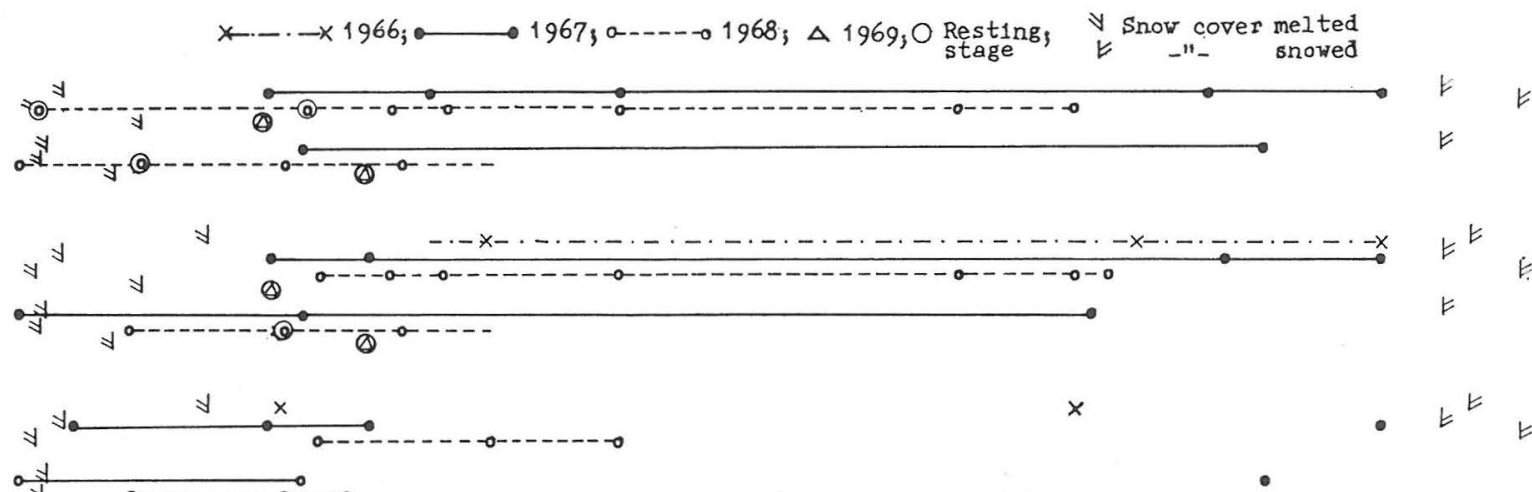

$x$
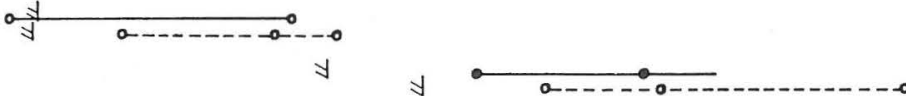

on Agrostis tenuis HÄMEENLINNA

INARI

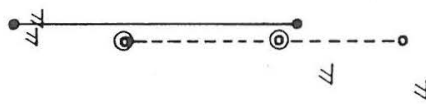

$x \cdot-\cdot-\cdot-\cdot-\cdot x$

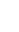

$\mathfrak{V}^{\mathfrak{E}}$

HÄMEERTL DNATA

on C. purpures

INARI

M. deschampsiae

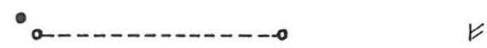

on Deschampsia caespitosa

INARI
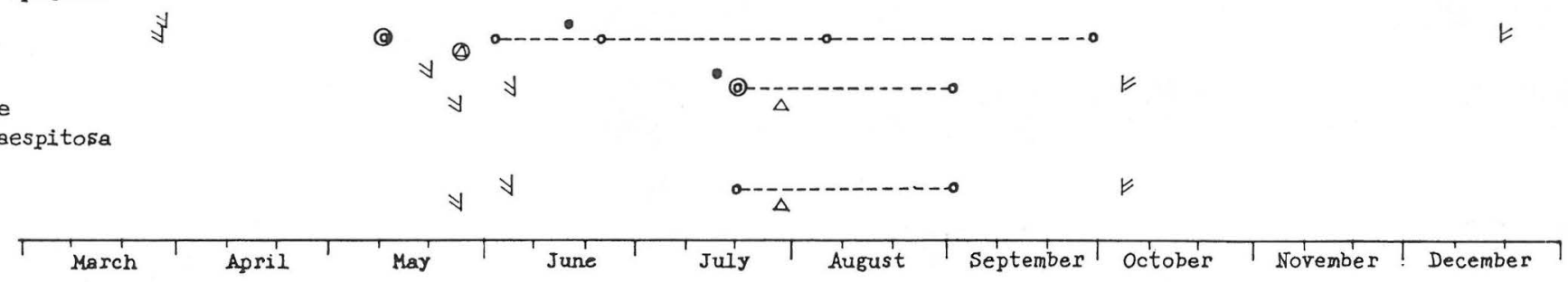

Fig. 2. Appearance of conidia and resting stages of Mastigosporium album, $M$. rubricosum and $M$. deschampsiae on different grass species in certain localities in the years 1966-69. 


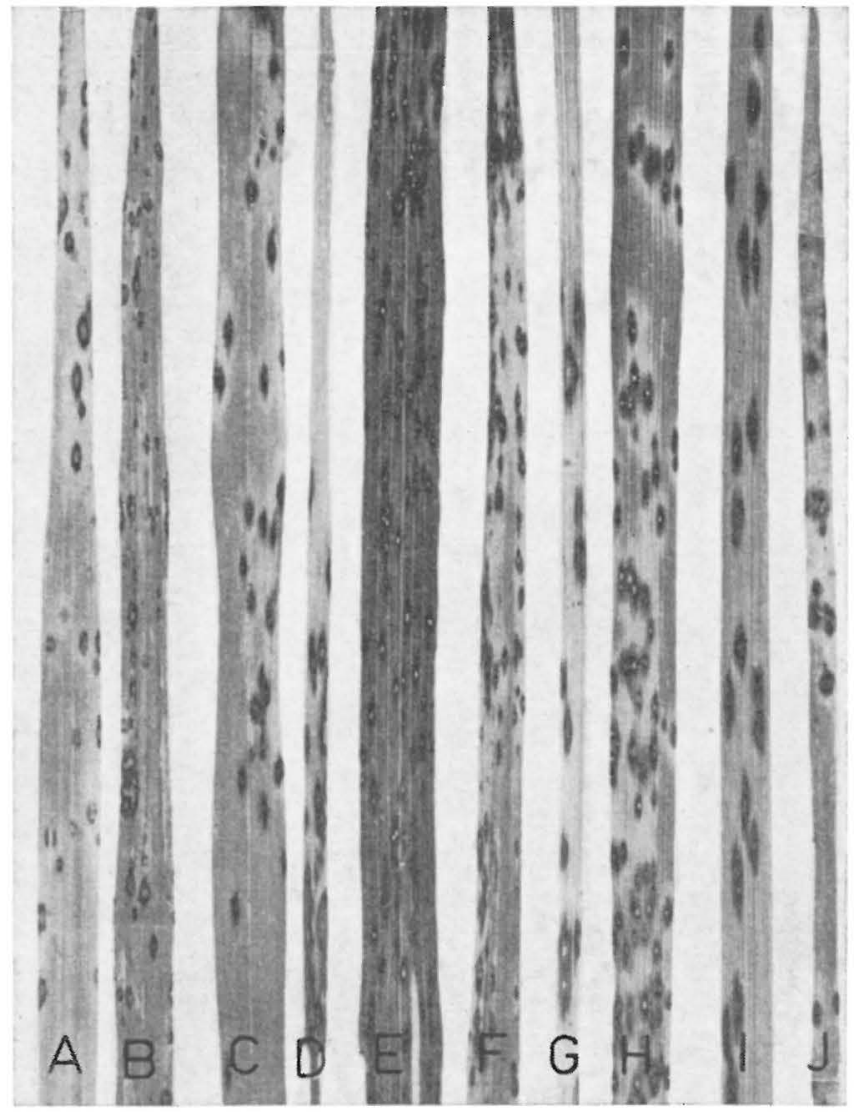

Fig. 3. Symptoms of disease. A-F: Mastigosporium rubricosum, G: $M$. deschampsiae, $\mathrm{H}-\mathrm{J}: M$. album; $\mathrm{A}-$ B: on Phleum pratense, C: on Dactylis glomerata, D: on Agrostis tenuis, $\mathrm{E}$ : on Calamagrostis epigeios, F: on C. purpurea, $H$ : on Alopecurus pratensis, I: on $A$. arundinaceus, $\mathrm{J}$ : on A. geniculatus; $\times 1$. as distinctly separate organisms. This opinion is also held by Sprague (1938), Sampson and Western (1939) and Bollard (1950).

During the present study $M$. album was found on Alopecurus pratensis and twice on $A$. geniculatus (at Viik). Of all the A. pratensis material (c. 200 samples) collected from different localities from Helsinki to Inari about $50 \%$, was infected by the fungus. $A$. pratensis was usually grown on the borders of fields. Viik was the only place where it was sown as a ley crop. A. geniculatus grew as a weed. Disease symptoms and spores of the fungus were found on the leaves during the period between early spring (March) and late autumn (November) (Fig. 2). The lesions in the growing grasses were most abundant in mid and late summer. Separate lesions often grew together forming larger areas of dead tissue. The lesions were rather large (Table $1)$, varying more in size than those of the other species of Mastigosporium (Fig. 3, H-J). The margins of the lesions varied from dark brown to umbra in colour, the centres from white to sand-coloured, growing lighter in proportion to the amount of conidia. The lesions were framed with a circle, mostly yellow to grewish orange in colour (cf. Sprague 1938).

Conidia groups grew on both sides on the leaves but were more abundant on the upper surface (Fig. $6 \mathrm{~A}-\mathrm{B}$ ). The formation and size of the conidia (about 500) averaged $50.3 \times 12.5 \mu \quad$ (range $32-86 \times 8-17 \mu$ ) (Table 1) showing little variation between the different localities and times of collection (Fig. 4 A-G). The spores were 3-8-, and most commonly, 4-septate. On the average, the spores were slightly larger than the ones reported by Sprgaue (1938) and slightly smaller than the ones reported by BolLARD (1954).

Inoculation tests on various grass species (Table 2) inoculated with conidia of $M$. album from natural infestations on Alopecurus pratensis, appeared disease symptoms 
Table 1. Size of spores and leaf flecks of Mastigosporium species on different hosts from different localities ${ }^{1}$ ) in the years 1967 -69.

\begin{tabular}{|c|c|c|c|c|c|c|c|c|c|c|}
\hline \multirow{2}{*}{$\begin{array}{l}\text { Mastigosporuim } \\
\text { species }\end{array}$} & \multirow{2}{*}{ Host } & \multirow{2}{*}{ 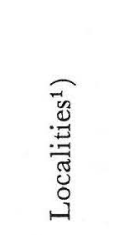 } & \multirow{2}{*}{ 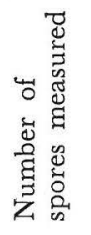 } & \multicolumn{2}{|c|}{ Size of spores, $\mu$} & \multicolumn{2}{|c|}{ Septa } & \multirow{2}{*}{ 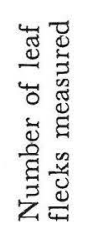 } & \multicolumn{2}{|c|}{ Size of leaf flecks, $\mathrm{mm}$} \\
\hline & & & & mean & range & mean & range & & mean & range \\
\hline \multirow[t]{3}{*}{ M. album } & Alopecurus pratensis & $1,4-8$ & 415 & $50.3 \times 12.5$ & $32-86 \times 8-17$ & 4.3 & $3-8$ & 925 & $2.3 \times 0.9$ & $0.5-22.0 \times 0.3-2.0$ \\
\hline & A. geniculatus & 1 & 100 & $52.5 \times 12.5$ & $43-70 \times 10-16$ & 4.1 & $3-5$ & 50 & $2.9 \times 0.8$ & $0.5-20.0 \times 0.5-1.5$ \\
\hline & A. arundinaceus & $\left.3^{2}\right)$ & 12 & $60.0 \times 12.4$ & $54-70 \times 10-15$ & 5.0 & $5-5$ & 156 & $3.2 \times 0.9$ & $0.7-6.0 \times 0.5-1.0$ \\
\hline \multirow[t]{7}{*}{ M. rubricosum } & Dactylis glomerata & $1,4-7$ & 395 & $38.9 \times 12.8$ & $26-48 \times 10-16$ & 3.4 & $3-5$ & 1150 & $1.7 \times 0.7$ & $0.5-8.0 \times 0.3-1.5$ \\
\hline & Phleum pratense & $1,4-8$ & 350 & $28.8 \times 9.0$ & $21-42 \times 6-12$ & 3.0 & $3-5$ & 1060 & $1.7 \times 0.8$ & $0.5-11.0 \times 0.3-2.0$ \\
\hline & Agrostis tenuis & $1,5,8$ & 120 & $38.2 \times 13.5$ & $23-45 \times 10-16$ & 3.0 & $3-3$ & 180 & $2.4 \times 0.8$ & $0.7-6.5 \times 0.3-1.5$ \\
\hline & Calamagrostis (mean) & $\begin{array}{l}1,2,4,5 \\
7,8\end{array}$ & 430 & $45.4 \times 14.0$ & $32-61 \times 8-20$ & 3.1 & $3-5$ & 500 & $2.7 \times 0.7$ & $0.5-9.0 \times 0.3-1.7$ \\
\hline & C.epigeios & 1,5 & 145 & $49.2 \times 16.0$ & $38-61 \times 11-20$ & 3.2 & $3-5$ & 175 & $2.3 \times 0.8$ & $0.5-15.0 \times 0.3-2.0$ \\
\hline & C. purpurea & $2,4,7,8$ & 255 & $44.3 \times 13.3$ & $32-58 \times 10-18$ & 3.0 & $3-4$ & 325 & $2.8 \times 0.7$ & $0.5-7.0 \times 0.3-1.7$ \\
\hline & C. lapponica & 8 & 30 & $38.0 \times 10.7$ & $33-52 \times 8-14$ & 3.0 & $3-4$ & & & \\
\hline M. deschampsiae & Deschampsia caespitosa & 8 & 160 & $58.0 \times 19.0$ & $40-72 \times 14-24$ & 5.7 & $4-8$ & 500 & $3.7 \times 1.1$ & $0.7-8.0 \times 0.3-2.0$ \\
\hline
\end{tabular}

1) U: Helsinki 1, Kirkkonummi 2, EK: Hamina 3, Iitti 4, EH: Hämeenlinna 5, St: Peipohja 6, ES: Mikkeli 7, InL: Inari 8.

2) in 1934 . 


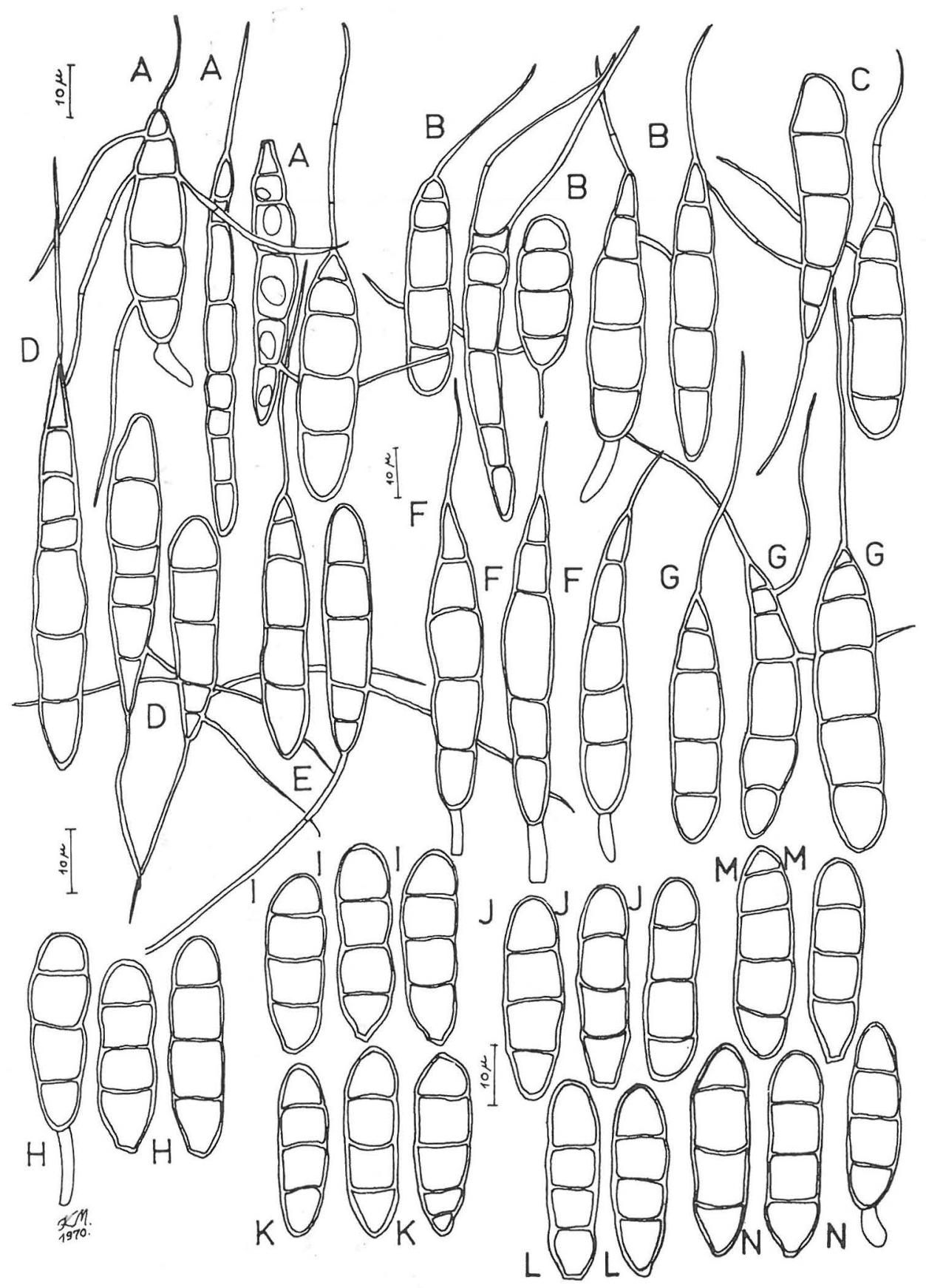

Fig. 4. Conidia of Mastigosporium album. A-E: on Alopecurus pratensis, F: on A. arundinaceus, $\mathrm{G}$ : on $A$. geniculatus. Conidia of $M$. rubricosum. $\mathrm{H}-\mathrm{L}$ : on Phleum pratense, $\mathrm{M}-\mathrm{N}$ : on Agrostis tenuis. A: Helsinki 15. IX. 1967, B, I, N: Hämeenlinna 13. IV. 1968, C, J: Peipohja 27. VII. 1968, D: Inari 20. VII. 1968, E: Mikkeli 28. VII. 1968, F: Hamina 28. VII. 1934, G: Helsinki 19. IX. 1967, H: 24. XI. 1967, K: Mikkeli 21. V. 1968, L-M: Inari 1. IX. 1968. $\mathrm{A}-\mathrm{G} \times 700, \mathrm{H}-\mathrm{N} \times 900$. 
and conidia on the leaves of $A$. pratensis and A. geniculatus.

Material examined

On Alopecurus arundinaceus:

EK: Hamina 28. VII. 1934, leg. Krohn; (HPP). On Alopecurus geniculatus:

U: Helsinki 19. IX., 23. X. 1969; (HPP).

On Alopecurus pratensis:

A: Ahvenanmaa, legg. Liro \& Roivainen; EH: Hämeenlinna, legg. Liro \& Heikinheimo; (HPP in Liro Mycoth. Fenn., 853, 854); U: Kirkkonummi, legg. Liro \& Heikinheimo; EP: Alavus, leg. Railonsala; (HPP).

U: Kirkkonummi (2 specimens), Siuntio ( $1 \mathrm{spec-}$ imen), Helsinki (55 specimens), Nummela (1 specimen); EH: Hämeenlinna (24 specimens), Iitti (1 specimen); St: Peipohja (1 specimen); ES: Mikkeli (2 specimens); InL: Inari (10 specimens); in 1966-69, (HPP).

Mastigosporium rubricosum (Dearn. \& Barth.) Nannf.

in Lundell \& Nannfeldt Fungi exsiccati Suecici Fasc. XVII-XVIII (1939). Syn. cf. Sprague (1938: 297-298).

\section{On Dactylis glomerata}

The most important and widespread host plant for $M$ : rubricosum is Dactylis glomerata. The disease has often been reported to be economically significant in Europe, e.g. in Denmark (Lind 1913), Norway (Jørstad 1924, 1945), Estonia (Kask 1959, Sarv 1966), Germany (Frank 1896, Schnetder \& Meyer 1963, Buhl \& Lange 1965, Frauenstein 1968), Britain (Wakefield 1918, Bollard 1950), France (Sagcardo 1911), the Soviet Union as well as in the USA (Sprague 1938, 1950), Canada (Greelman 1956), and New Zealand (Wenham \& LAтch 1958). The fungus reported also infects $D$.ascherssoniana Graebn. (Bollard 1950), Alopecurus pratensis and Lolium perenne (BuHL \& LANGE 1965).

In this study $M$. rubricosum was found on D. glomerata in numerous localities in southern and central Finland where this grassspecies is grown in pastures and on the borders of fields. It is almost nonexistent in the northern parts of the country (cf. Hulten 1950, Paatela 1953). About $27 \%$ of all the material studied (c. 1000 samples) was infected by the fungus.

Disease symptoms and viable conidia occurred on the leaves from spring thaw
(March) to late autumn (November) (Fig. 2). It was characteristic of the disease that leaf flecks were most abundant at the lower parts of the plant, particularly on leaf sheaths and leaf parts next to the sheath. Further more, the disease was found in the same areas, even on the same individual plants in different years. On the average, there were fewer lesions on Dactylis glomerata than on Alopecurus pratensis and $C a$ lamagrostis spp.

Leaf-fleck (Table 1, Fig. 3, G) margins were mostly dark brown in various shades of brown - umbra - cocoa. The centre was orangish grey to putty in colour. A greyish orange to sand-coloured circle usually surrounded the margins (cf. Sprague 1938, Bollard 1950). The average size of the conidia (about 400 ) was $38.9 \times 12.8 \mu$ (range $26-48 \times 10-16 \mu$ ) (Table 1 ) and varied little with respect to place or time of sample collection. They were mostly 3 -septate, occasionally 4-5-septate. Bollard (1950) has also recorded spores with 4 to 5 septa but Sprague (1938) has only observed spores with 3 septa. The spore formation was mostly in agreement with Sprague's (1938) findings (Fig. 6, F). In addition, some longer, narrower spores with more morphological variation were found (Fig. 5, A, B, E). Several types of spores appeared in the same crop at different times. The 30 spores with 3 septa which were measured - these were raised on potato dextrose agar - averaged $36.6 \times$ $13.0 \mu$ with variation of $29-45 \times 12-14 \mu$. Their sizes anf morphological tendencies corresponded with those of spores found on diseased leaves in the field.

In the inoculation experiments on various grass species (Table 2) the spores of $M$. rubricosum from natural infestation on Dactylis glomerata produced symptoms of disease. Conidia were produced only on the leaves of $D$. glomerata.

\section{Materials examined}

A: Jomala (3 specimens); U: Espoo (1 specimen), Helsinki (162 specimens), Tikkurila (14 specimens); V: Mietoinen (7 specimens); EK: Anjala (1 specimen); EH: Iitti (1 specimen), Tammela (1 specimen), Hämeenlinna (18 specimens), Pälkäne (4 specimens); St: Peipohja (25 specimens); ES: Mikkeli (24 specimens); PH: Laukaa (3 specimens); in 1966-69, HPP). 


\section{On Phleum pratense}

Phleum pratense has been reported as a host for the fungus in Denmark (Lindau 1907, Lind 1913), Norway (Jørstad 1924, 1945) and the USA (SpraGUE 1950). In Finland, Rainio described (1936) the disease as occurring particularly in areas that produce timothy seed. According to Brummer (1937) the disease was highly injurious at the Tammisto Plant Breeding Station during the summers of 1933, 1934 and 1936. Although described as $M$. album and Dilophospora alopecuri by RAINIo and BRUMmer (cf. p. 1) the fungus in question is probably also $M$. rubricosum, as is indicated by Figure 4 presented by RaInIo (1936:9) and ti- mothy material in the collections, established by BRUMMER in the summer of 1934 (cf. p. 8), of the Department Plant Pathology of Helsinki University.

In the present study M. rubricosum was found on Phleum pratense from different locadities ranging from Helsinki to Inari. $13 \%$ of the material studied (c. 700 samples) was infected by the fungus.

The disease was the most intense from early spring to early summer and again late in autumn, particularly on lower leaves near the ground (Fig. 2). More than half of the leaf surface might be covered with lesions. On the other hand leaf flecks are usually scarce in summer. The lesions were fairly

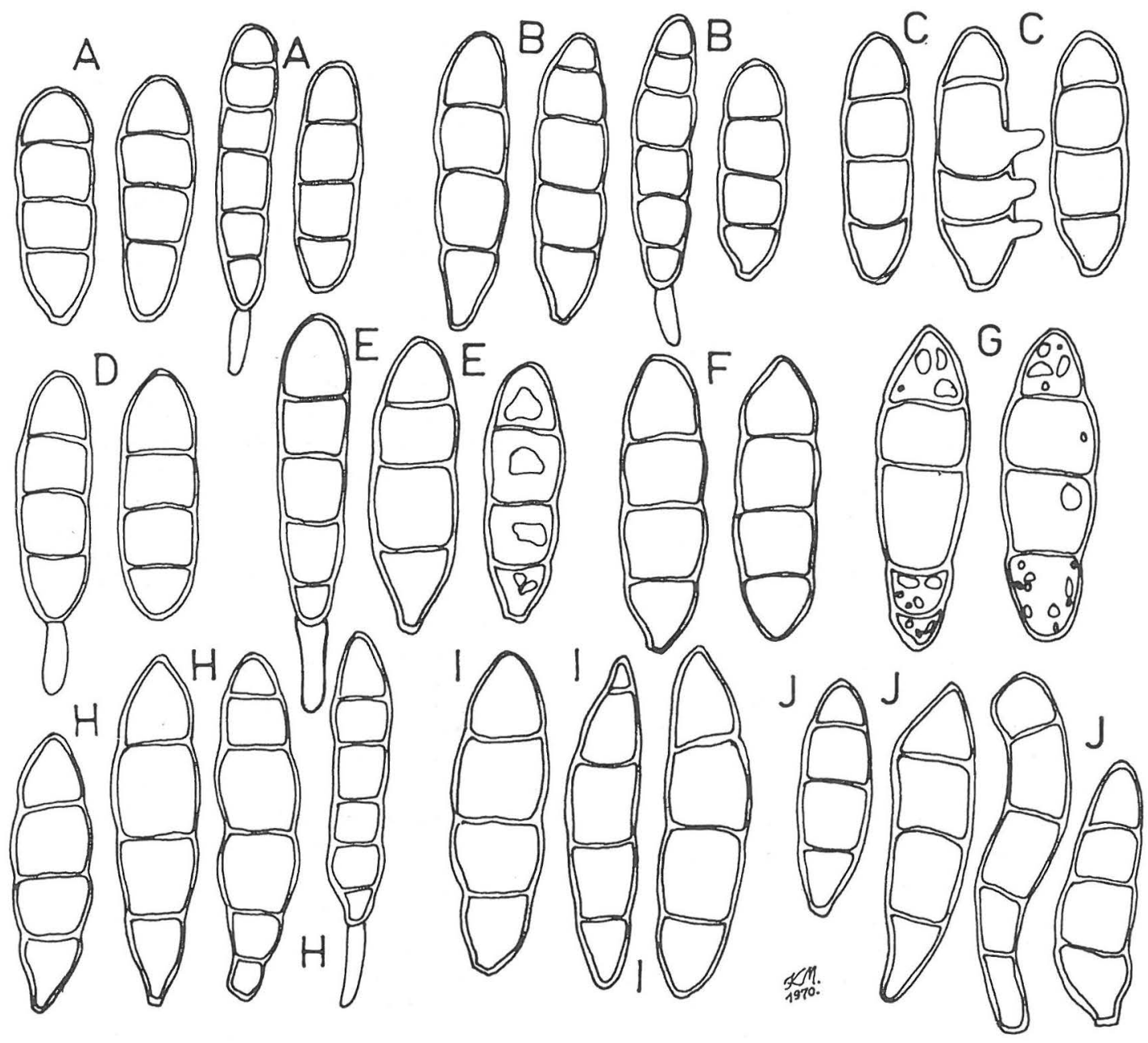

Fig. 5. Conidia of Mastigosporium rubricosum. A-E: on Dactylis glomerata, $\mathrm{F}-\mathrm{H}$ : on Calamagrostis epigeios, I: on C. purpurea and J: on C. lapponica. A: Helsinki 17. V. 1968, B, H: Hämeenlinna 17. VI. 1967, C, I: Mikkeli 21. V. 1968, D: Peipohja 15. V. 1968, E: Iitti 28.5. 1967, F: Helsinki 2. IX. 1951 (HPP in Liro: Mycoth. Fenn., 855), G: Kirkkonummi 15. VIII. 1968, J: Inari 21. VII. 1968. $\mathrm{A}-\mathrm{D}, \mathrm{F}, \mathrm{H} \times 800, \mathrm{E}, \mathrm{I}, \mathrm{J} \times 900, \mathrm{H} \times 1000$. 


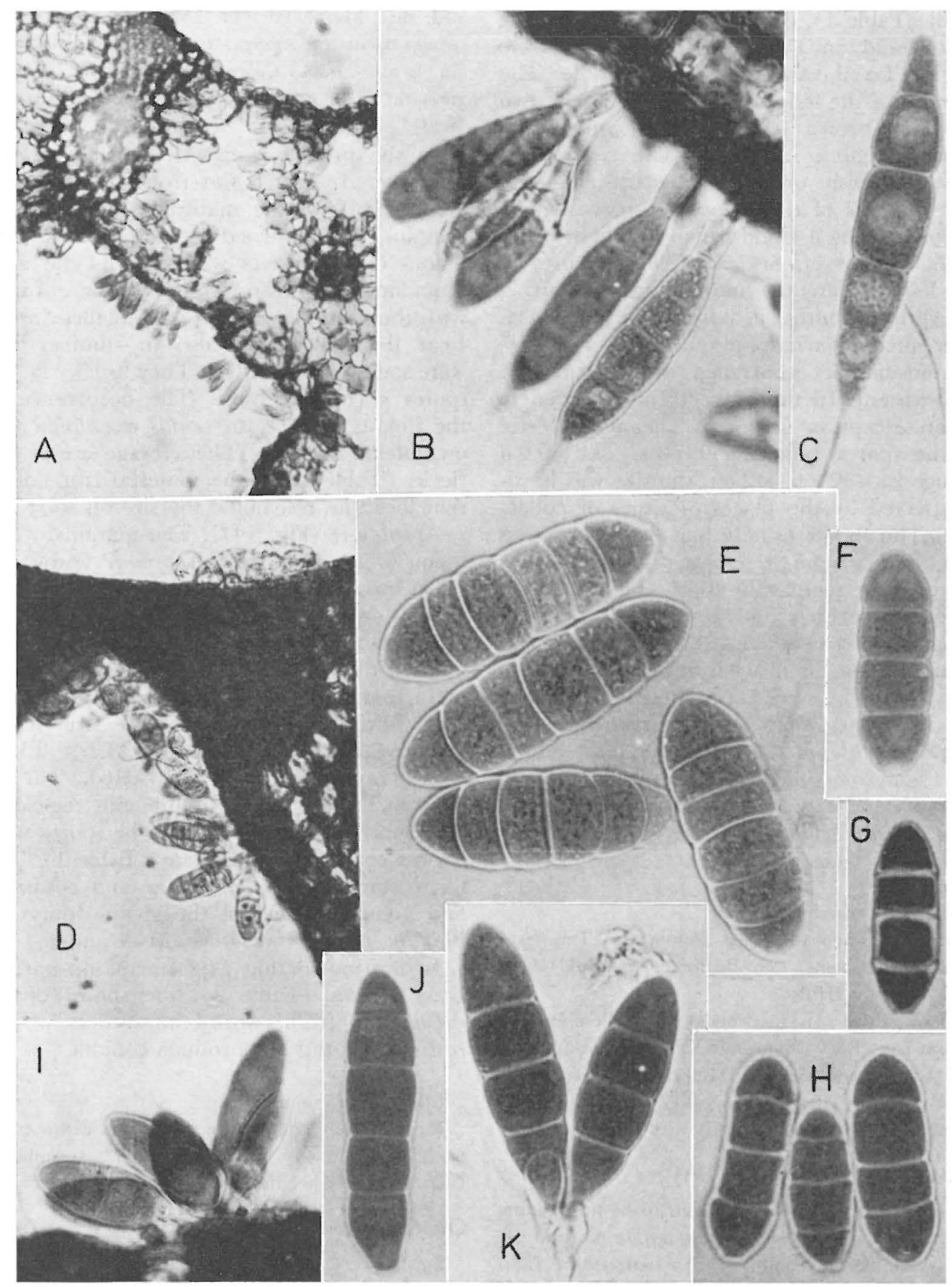

Fig. 6. Conidia of Mastigosporium album. A-C: on Alopecurus pratensis, $M$. deschampsiae D-E: on Deschampsia caespitosa, $M$. rubricosum F: on Dactylis glomerata, G: on Agrostis tenuis, $\mathrm{H}$ : on Phleum pratense and $\mathrm{I}-\mathrm{K}$ : on Calamagrostis epigeios. A- $\mathrm{C}$, F: Helsinki 5. VI. 1968, D-E: Inari 1. IX. 1968, H: Hämeenlinna 13. IV. 1968, I-K: 17. VI. 1967, J: 15. VII. 1967. $\mathrm{A} \times 90, \mathrm{D} \times 135, \mathrm{~B}, \mathrm{I} \times 900, \mathrm{C}, \mathrm{E}-\mathrm{H}, \mathrm{J}, \mathrm{K} \times 1075$. 
small (Table 1), comparable in size with the ones found on Dactylis glomerata (Fig. 3, A-B). Local variation was negligible. The margins of the lesion were dark redish brown - violet brown - dark violet, sometimes ruby or umbra in colour. The centre was mostly greyish orange to cream coloured. The margins of the lesion were occasionally surrounded by a circle which was light orange in colour (cf. Sprague 1950). Spores in the lesions were the most abundant during the spring months, i.e., from April to May, with some occurrence also in October, whereas midsummer occurrence was minimal or non-existent. In this respect Inari proved to be an exception (Fig. 2). The average size of the spores (about 350) was $28.8 \times 9.0 \mu$ (range $21-42 \times 6-12 \mu$ ), the size was hardly affected by the places or times of collection. The spores usually had 3 septa; spores with 4 or 5 septa were rare (Table 1 ). The spores were regular in form and similar in different localities and at different times of the growing season (Figs. 4, $\mathrm{H}-\mathrm{L}$ and $6, \mathrm{H}$ ).

In experiments in wich different grass species (Table 2) were inoculated with conidia of M. rubricosum that were naturally produced on Phleum pratense, abundant conidia and symptoms of disease appeared on $P$. pratense and Dactylis glomerata but on Festuca rubra, Lolium perenne and Poa pratensis they were scarce.

Material examined

EH: Jokioinen 1929, leg. Pesola; U: Tammisto 1934 (5 specimens), leg. Brummer; Helsinki 1951, leg. Mäkelä; (HPP).

U: Helsinki (16 specimens); V: Mietoinen (1 specimen); EH: Hämeenlinna (18 specimens), Iitti (2 specimens); ES: Mikkeli (6 specimens); St: Peipohja (4 specimens); InL: Inari (12 specimens); in 1966-69; (HPP).

\section{On Agrostis tenuis}

The species of Agrostis known to be host plants for $M$. rubricosum are: A. stolonifera $\mathrm{L}$. and $A$. tenius Sibth. in Denmark (Lindau 1907, Lind 1913), A.tenius in Iceland (Larsen 1932) and in Norway (Jørstad 1945), A. stolonifera in Britain (Bollard 1950) and in Germany (Schneider \& Meyer 1963), on Agrostis spp. with the name M. album also (SORAUER 1874: 354), and in addition to these, A.palustris Huds. and A. verticillata Vill in the USA (Sprague 1938).

Mastigosporium rubricosum var. agrostidis Bol- lard. Brit. Mycol. Soc. 33: 262-263 (1950). The species occurs on Agrostis stolonifera in Great Britain. It also attacks Calamagrostis, but not Dactylis glomerat L. or other species of Agrostis (BoLLARD 1950).

In the present study $M$. rubricosum was found on Agrostis tenius from any localities. About $35 \%$ of the material studied (c. 80 samples) was infected by the fungus. The lesions on the leaves were usually the most abundant early in spring and late in autumn, with the spores appearing only at these times. Leaf flecks occurred also in summer and were sometimes plentiful. They usually lacked spores except in Inari. The occurrence of the fungus on Agrostis tenuis resembled that on Phleum pratense. The average size of leaf flecks (Table 1) in the material from different localities resembled the size on Alopecurus pratensis (Fig. $3 \mathrm{D}$ ). The margins of the lesion were dark reddish brown (ruby) violet brown - cinnamon brown, the centres, grayish orange - cinnamon brown in colour (cf. Sprague 1938).

With the exception of the material collected in Inari, the spores produced in the lesions were fairly scarce. The average size of the spores was (about 120 spores) $38.2 \times 13.5 \mu$ with a range of $23-45 \times 10-16 \mu$. No significant variation was found with regard to place and time of collection. The spores were almost consistently 3-septate (Table 1 ). The formation was highly regular and contstant and greatly resembled the spores found on Phleum pratense (Figs. 4, M-N and 6, G).

In the inoculation experiments on various grass species (Table 2), the spores of $M$. rubricosum from natural infestation on $\mathrm{Ag}$ rostis tenuis did not produce conidia.

Materials examined

U: Helsinki (10 specimens); EH: Hämeenlinna (12 specimens; ES: Mikkeli (1 specimen); InL: Inari (4 specimens); (HPP).

\section{On Calamagrostis sp.}

Species of Calamagrostis recorded as host plants for M. rubricosum: C. Halleriana P. Beauv. in the Erzgebirge mountain chain, Germany (Frank 1880, cf. Lindau 1907: 402), C. epigeios (L.) Roth., C. lanceolata Roth., C. arundinacea (L.) Roth., and $C$. purpurea Trin., in Scandinavia (LiNDAU 1907, Lind 1913, Lundell \& Nannfeldt 1939, Jørstad 1945), C. canescens (Michx.) Beauv. and C. scabra Presl in the USA (Sbrague 1938). 
Table 2. Results of inoculation tests in the laboratory with Mastigosporium species in the summer of 1968.

Seedlings

Inoculated with spore suspension

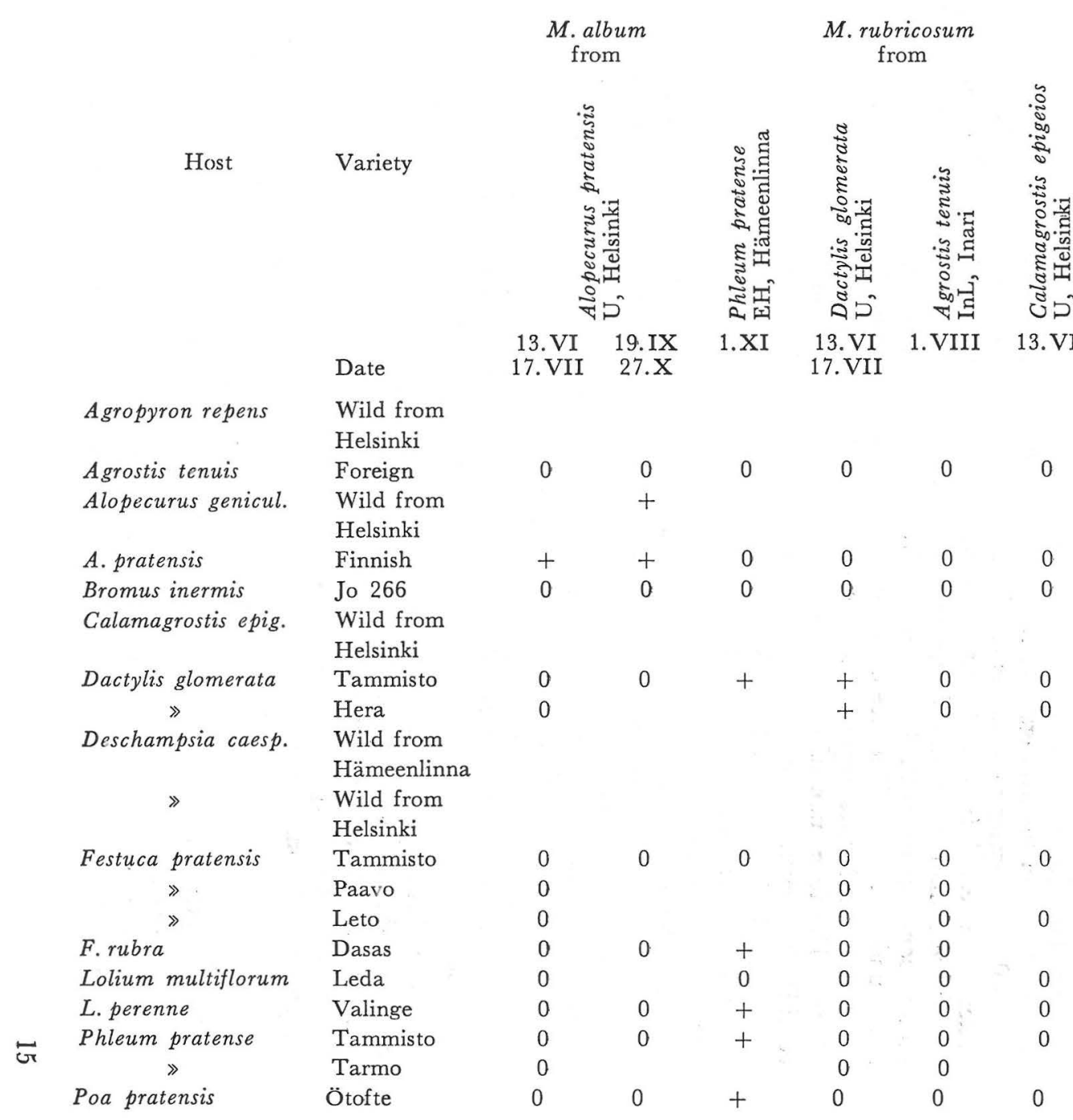

Leaves

Inoculated with pieces of diseased leaves

$$
\begin{array}{ccc}
\text { M. album } & & \text { M.desch- } \\
\text { from } & \text { M. rubricosum } & \text { ampsiae } \\
\text { from } & \text { from }
\end{array}
$$

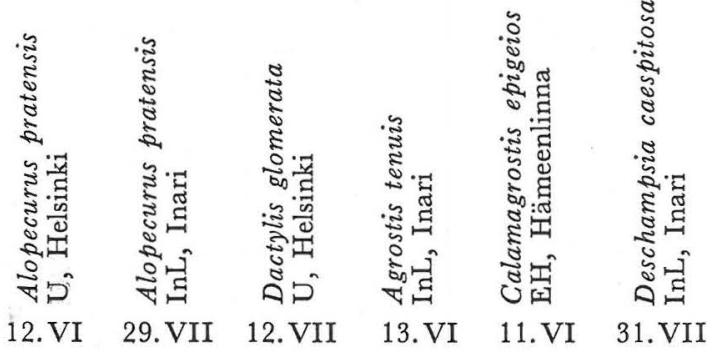

0

$$
0
$$

$0 \quad 0$

0
0
0
0
0

$\begin{array}{lllll}0 & 0 & 0 & 0 & 0 \\ 0 & 0 & 0 & & 0 \\ 0 & 0 & & 0 & \\ 0 & 0 & 0 & 0 & 0 \\ & 0 & & 0 & \\ 0 & 0 & 0 & 0 & 0 \\ 0 & 0 & 0 & 0 & 0\end{array}$


In the present study $M$.rubricosum was found on Calamagrostis epigeios, C. purpurea, and C. lapponica (Wahlenb.) Hartm. in various localities ranging from Helsinki to Inari. About $40 \%$ of the material studied (c. 50 samples) was infected by the fungus. All the material was collected from the borders of fields. The disease was most intense in mid-summer. The first symptoms of disease appeared on the leaves in the period from the end of May to the beginning of June. No spores were noted after September (Fig. 2 ), which was likewise in agreement with the above, old samples. In this respect the disease differed from that found on other grasses. Lesions were usually numerous (Table 1). The leaf fleck margins were dark brown dark ruby - cocoa, the centres light orangish grey to white in colour. A narrow circle, apricot yellow in colour, usually surrounded the margins (Fig. 3, E-F) (cf. Sprague 1938). The conidia were the most abundant in midsummer. The size of the conidia (430) was $45.4 \times 14.0 \mu$ on the average (range 32-61 $\times 8-20 \mu$ ), varying to some extent in the materials collected from different localities. Spores were most commonly 3-septate, even though some spores with 4 (5) septa were also found (Table 1). The size of spores agreed with the figures reported by Sprague (1938). The formation of the spores varied considerably even within individual samples (Figs. 5, G-J and 6 I-K). The size and formation of the spores also varied conciderably in the samples of $M$. rubricosum on D'actylis glomerata, Phleum pratense, and Agrostis tenuis. These spores were considerably larger, more tapering at the ends, contracted at the septa and showed greater morphological variation (Figs. 5 and 6). Spores of the type described by SRPaGue (1938) were also found, especially among young spores.

In experiments in which different grass species (Table 2) were inoculated with conidia of $M$. rubricosum that were naturally produced on Calamagrostis epigeios, disease symptoms and conidia appeared only on $C$. epigeios.

Materials examined

On Calamagrostis arundinacea:

EH: Hämeenlinna in 1927, legg. Liro \& Heikinheimo (HPP).
On Calamagrostis epigeios:

PH: Jyväskylä in 1913, leg. Liro; PS: Kuopio in 1915, leg. Lönnbohm; U: Helsinki in 1929, leg. Heikinheimo; LK: Sortavala in 1929, legg. Liro \& Heikinheimo, U: Papinkylä in 1936, leg. Lehtola (all specimens HPP). In these samples the species had been incorrectly described as Dilophia graminis (cf. p. 1). U: Helsinki in 1951 leg. Roivainen (in Liro: Mycoth. Fenn., 855). In this sample the species had been incorrectly described as $M$. album.

$\mathrm{U}$ : Helsinki (2 specimens); EH: Hämeenlinna (9 specimens); 1968-69; (HPP).

On Calamagrostis purpurea:

U: Helsinki 1958, leg. Mäkelä (HPP).

U: Kirkkonummi (1 specimen); Espoo (2 specimens); EH: Iitti (1 specimens); InL: Inari (4 specimens), in 1968-69; (HPP).

On other grass-species

In addition to the conidia mentioned above, the author only rarely found conidia of Mastigosporium rubricosum in the field on the following grass species:

Festuca pratensis, F. rubra (cf. KAsK 1959), Lolium perenne (cf. BuHL \& LANGE 1956, Lagey 1967), and Poa pratensis (cf. Byzova 1961). In inoculation experiments (Table 2) in which conidia of $M$. rubricosum naturally produced on Phleum pratense were used, a few conidia and symptoms of disease also appeared on Festuca rubra, Lolium perenne and Poa pratensis.

Material examined

On Festuca pratensis:

U: Helsinki 17. V., 27. V., 10. VII., 9. IX. 1968; EH: Hämeenlinna 23. VI. 1968.

On Festuca rubra:

U. Helsinki 10. VII. 1968; EH: Hämeenlinna 13. IV. 1968.

On Lolium perenne:

U: Helsinki 23. X. 1967, 17. V. 1968.

On Poa pratensis:

EH: Hämeenlinna 10. X. 1969; InL: Inari 20. VII. 1968, 13. VI. 1969.

Mastigosporium deschampsiae Jørstad Forh. Vidensk. Selsk. Krist. 19: 27-28 (1947). This species frequently attacks Deschampsia caespitosa L. in Norway, where it was isolated in six localities in 1885-1931 (JøRSTAD 1947). It was recorded in Britain for the first time in 1948 (Austwick 1954).

M. deschampsiae was found for the first time in the summer of 1968 (July 21, Sep- 
tember 1) on the leaves of Deschampsia caespitosa at Muddusniemi, Inari. In the following summer, the species was again found in the same locality, though it had not yet been recorded elsewhere. The infected plants were growing on an old ley in a rather humid place near the shore of Muddusjärvi lake. Some individual plants were severely diseased, whereas others showed no trace of disease. Similar observations have also been made by Austwiak (1954).

The leaves showed numerous symptoms of disease. The lesions were rather large (about 500 lesions), $3.7 \times 1.1 \mathrm{~mm}$ on the average, with a range of $0.7-8 \times 0.3-2$ " $\mathrm{mm}$ (Table 1). Austwick (1950) stated that the size of the lesions in his material was up to $3 X$ $1 \mathrm{~mm}$. The margins of the lesions were umbra in colour, the centres being yellowish white - greyish orange. The darker margin was usually surrounded by a circle which was pale yellow - greyish orange in colour (Fig. 3 G). (cf. Jørstad 1947, Austwick 1954).

Conidia groups grew on both surfaces on the leaves, often as heaped-up groups between the ridges (Fig. 6 D). The size of the spores (160) averaged $58.0 \times 19.0 \mu$ (range $40-72-14-24 \mu)$ and that of the conidiophores, $16-32.4 \times 4-5 \mu$. The spores were most commonly (55 per cent) 5 -septate with a frequent occrurrence of 6 septa (31 per cent), the whole range of variation being 3 to 7 septa (3-septate/1 per cent, 4-septate/ 4 per cent, 7 -septate $/ 9$ per cent). The spores were partly rounded and flattened, at leats at the end, partly rather tapering at both ends (Fig. 6 E). According to JøRstad (1947) the conidia were $40-68 \times 12.5-20 \mu$ in size, mostly 6-, also 4- to 7-septate with conidiophores of $13-23 \times 4-5.5 \mu$; according to Austwiak (1954) the conidia were (40) 50 78 (84) $\times 17-28 \mu$ in size and 3- to 7-, but most commonly, 5-septate.

In experiments in which various grass species (Table 2) were inoculated with spores of $M$. deschampsiae that were naturally produced on the leaves of Deschampsia caespito$s a$, brown lesions appeared only on the leaves of D. caespitosa. About 60 per cent of the 30 leaves inoculated had such lesions. No conidial development took place. Austwick (1954) also noted that infection always failed in summer.

The first record of $M$. deschampsiae on Deschampsia caespitosa in Finnish Lapland agrees well with the localities where it has been previously recorded in Norway (JøRSTAD 1947) and Britain (Austwick 1954). It also coincided with what Austwick (1954) has observed; namely, that the disease appeared on viable leaves only from late autumn (November) till early spring (April) and that typical spores were produced in cultures only at $+5^{\circ} \mathrm{C}$.

Material examined:

InL: Inari 21. VII., 1. IX. 1968, 14. VII., 15. IX. 1969; (HPP).

\section{Resting stage of Mastigosporium-fungi}

SPRAGUe (1938) has found »small partially embedded stromatic or sclerotic mycelia that resemble pycnidiay in old colonies of $M$. rubricosum isolated from Dactylis glomerata. Bollard (1950) has also recorded similar bodies with a diameter of 200$350 \mu$ in colonies of $M$. album and $M$. rubricosum

Table 3. Resting stage of Mastigosporium species on different hosts in different localities in the years 1967-70.

\begin{tabular}{|c|c|c|c|c|c|}
\hline $\begin{array}{l}\text { Mastigosporium } \\
\text { species }\end{array}$ & Host & $\begin{array}{l}\text { Locali- } \\
\text { ties }^{1} \text { ) }\end{array}$ & $\begin{array}{l}\text { Sampling } \\
\text { date }\end{array}$ & $\begin{array}{c}\text { Diameter of } \\
\text { stromata } \\
\mu \\
\text { range }\end{array}$ & $\begin{array}{c}\text { Size of spores, } \\
\mu \\
\text { range }\end{array}$ \\
\hline \multirow[t]{3}{*}{ M. album } & Alopecurus pratensis & $1,5,7$ & 28. III-25. V & $90-1100$ & $30-58 \times 10-15$ \\
\hline & & 8 & 16. VI-20. VII & $220-440$ & $43-54 \times 12-14$ \\
\hline & & 1 & 12. $\left.\mathrm{I}^{2}\right)$ & $150-430$ & $50-60 \times 12-16$ \\
\hline \multirow[t]{4}{*}{ M. rubricosum } & Dactylis glomerata & $1,5,6,7$ & 7. $\mathrm{V}-25 . \mathrm{V}$ & $90-445$ & $33-50 \times 10-14$ \\
\hline & Calamagrostis epigeios & 1 & 25. V & $150-370$ & $45-61 \times 11-18$ \\
\hline & C. purpurea & 7 & 21. V & $100-350$ & $42-58 \times 10-16$ \\
\hline & C. lapponica & 8 & 20. VII & $180-330$ & $24-52 \times 8-14$ \\
\hline
\end{tabular}

1) U: Helsinki 1, EH: Hämeenlinna 5, St: Peipohja 6; ES: Mikkeli 7; InL: Inari 8.

2) in the laboratory. 


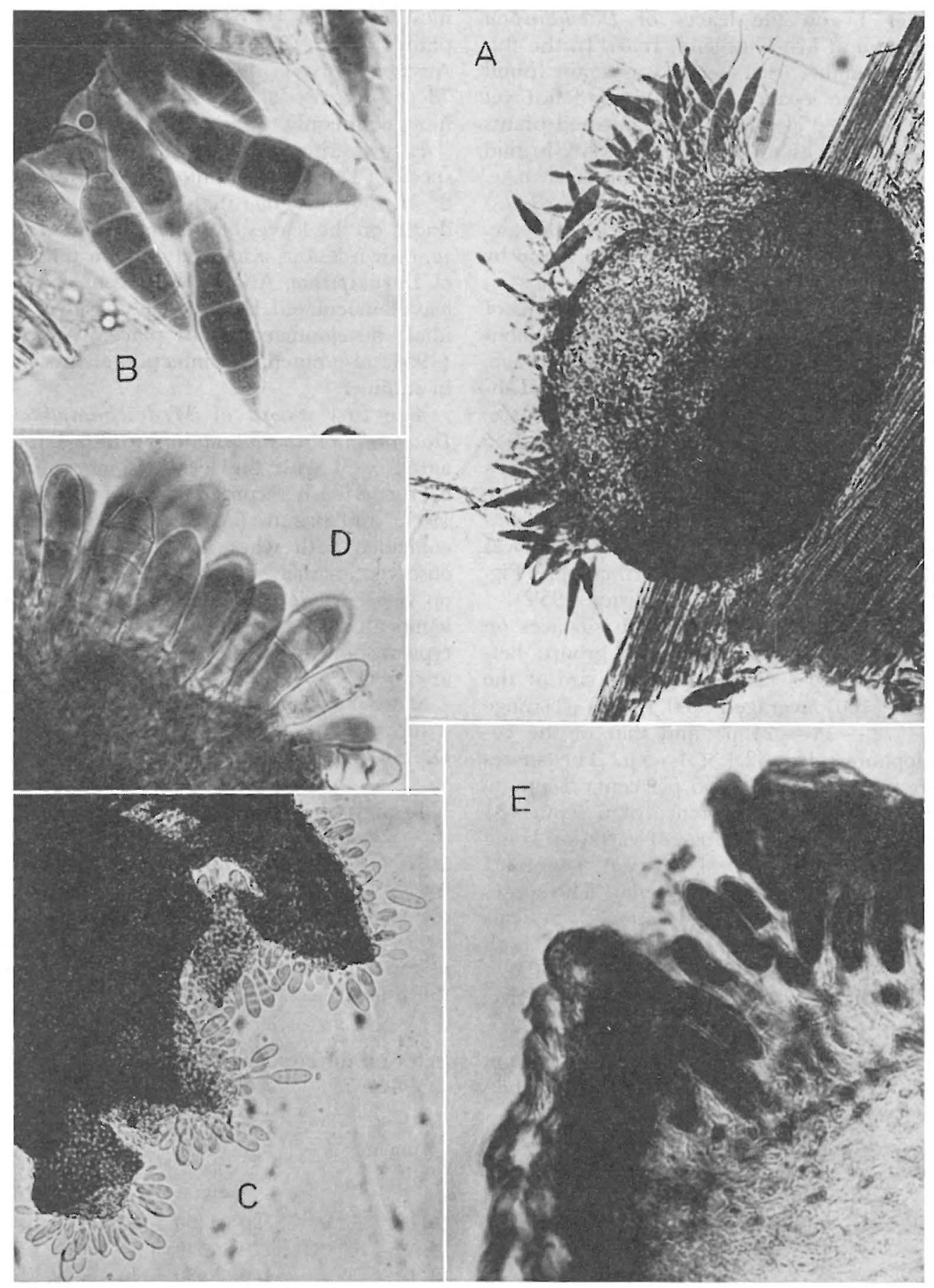

Fig. 7. Resting stage of Mastigosporium album A-B: on Alopecurus pratensis, of M. rubricosum G-D: on Daclylis glomerata, and E: on Calamagrostis lapponica. A: stroma with conidia in inoculation test 1.XI. 1969, B: conidia Helsinki 7. V. 1969, C: stroma with conidia Hämeenlinna 11. V. 1968, E: stroma with conidia Inari 21. VII. 1968. A, G $\times 180, \mathrm{E} \times 450, \mathrm{~B}$, $\mathrm{D} \times 900$. 
(after one mont's growth) isolated from the leaves of Dactylis glomerata and Agrostis stolonifera. Austwick's observations (1954) on colonies of $M$. deschampsiae, $0.5-1.5 \mathrm{~mm}$ in diameter, agree with this. In all the above-mentioned instances cool growing conditions increased the amount of sclerotia whereas there was no trace of further development or spore formation. Nor are there any field reports of similar bodies being found on the dead leaves of grasses.

In the present study naturally occurring round, smooth, stromatic bodies growing on the dead leaves of various grass species were found in several localities early in spring and at the beginning of summer, i.e. from March to June, 1967-69 (Table 3, Fig. 2). They grow on the surface tissue of the leaf (Fig. $7, \mathrm{~A})$. Their thin outher wall is dark brown in colour and consists of cellular structures (Fig. $7 \mathrm{~A}, \mathrm{C}$ ), resembling the wall of a pycnidium or cleistothecium. The inner part of a stroma is solid, light-coloured and cellular (Fig. 7 D, E), with conidiophores and conidia of Mastigosporium emerging from it (Fig. $7 \mathrm{~A}, \mathrm{D}$ ). The size and shape of the conidia were the same as those of conidia occurring on leaf flecks (Table 1). The size of the stromata varied considerably, stying within the range of (90) 270 (1100) $\mu$ (Table 3 ). However, there were no significant variations with regard to place and time of collection. In general, the srtomata were not found immediately after the snow had melted, at least not ones with conidia. The highest rates of occurrence of stromata and conidia were obtained about one month after the snow had melted.

A stromatic resting stage of the species (Table 3) was recorded on Alopecurus pratensis from several localities as well as in inoculation tests after one and a half month's growth at $+5^{\circ} \mathrm{G}$ in the laboratory. Corresponding stromata of $M$. rubricosum with conidia were found on the dead leaves of Dactylis glomerata, Calamagrostis epigeios, C. purpurea, and C. lapponica. On Agrostis tenuis only one occurrence was recorded (Hämeenlinna 13. IV. 1968), this one without conidia. No stromata were found on the leaves of Phleum pratense and Deschampsia caespitosa.

Materials examined

On Alopecurus pratensis:

$\mathrm{U}$ : Helsinki (4 specimens); EH: Hämeenlinna 15. IV. 1968, 25. V. 1969, ES: Mikkeli 21. V.
19.68; InL: Inari 16. VI. 1967, 20. VII. 1968; (HPP).

On Dactylis glomerata:

$\mathrm{U}$ : Helsinki (4 specimens); EH: Hämeenlinna (2 specimens); St: Peipohja 15. V. 1968; ES: Mikkeli 21. V. 1968; (HPP).

On Calamagrostis epigeios:

EH: Hämeenlinna 17. VI. 1967, 25. V. 1969; (HPP).

On Calamagrostis purpurea:

ES: Mikkeli 21. V. 1968; (HPP).

On Calamagrostis lapponica:

InL: Inari 20. VIII. 1968; (HPP).

\section{Discussion}

About 44 per cent of the total arable land of Finland is covered by grass (1210 500 hectares) and for the most part constitutes temporary leys (Maataloustilastollinen Kuukausikatsaus 1969). In addition, wild grass is common throughout the country (HULTéN 1950, Paatela 1953). This makes the spread of grass diseases possible. Studies carried out by the author indicate that this notion is correct, at least as far as species of Mastigosporium are concerned. Another important factor contributing to the frequent occurrence of these fungi in this coutry is evidently the Finnish climate with its long, humid spring and autumn as well as its short and cool summer. The length of the thermal spring $\left(0^{\circ}-10^{\circ} \mathrm{C}\right)$ varies from 45 to 65 days, that of the thermal autunm $\left(10^{\circ}-0^{\circ} \mathrm{C}\right)$ from 45 to 85 days. The length of the growing season is from 100 to 180 days. The monthly precipitation during the growing season varies from 35 to $80 \mathrm{~mm}$, and is lower early in the season than in the autumn (Kolkk 1966). Mastigosporium species thrive in humid, rainy, and foggy weather (SRPAGUE 1938, 1950, Bollard 1950, Austwick 1954, Buhl \& Lance 1965, Sarv 1966). They favour relatively low temperatures, showing growth and conidia germination even at $+5^{\circ} \mathrm{C}$, with an optimum over the range from $10^{\circ}-$ $20^{\circ} \mathrm{C}$. Their growth stops at a temperature exceeding $+25^{\circ} \mathrm{C}$ (Bollard 1950, Austwick 1954). Climatic conditions also seemed to govern the occurrence of Mastigosporium in Inari. The conidia of Mastigosporium were abundant in Inari during the whole growing season even on grass species (Phleum pratense, Agrostis tenuis) that were observed to 
be free of conidia in the southern part of the country in summer.

The natural occurrence of the stromatic, conidial resting stage of Mastigosporium in Finland was evidently connected with the long winter and the persistent snow cover. The length of the thermal winter $\left(0^{\circ}-0^{\circ} \mathrm{G}\right)$ in this country varies from 100 to 205 days (Kolkki 1966), and the snow cover plays an important role in affecting the soil temperature as well as the dormant period of plants (YLIMÄKI 1962). It is evident that Mastigosporium species fail to produce the resting stage under warmer conditions. This might explain why no naturally occurring resting stage of Mastigosporium has been found elsewhere, whereas stromatic bodies without conidia have been noted in old cultures that have been kept cool (SRPAGUe 1938, Bollard 1950, Austwick 1954). Sharing the experience of other researchers (BolLARD 1950), the author was unsuccessful in finding a perfect stage.

No resting stage of Mastigosporium was found on Phleum pratense and Agrostis te- nuis, whereas viable conidia were found in abundance even as early in spring as the time when the snow still partly covered the leaves. Since the occurrence of conidia was limited in autumn, it can be concluded that fungus developed while still under the snow. This is confirmed by Bollard's (1950) observation that $M$.rubricosum remains viable on the leaves of Dactylis glomerata at least for 6 weeks under the snow. SArv's (1960) observations on the overwintering of $M$. album growing on Alopecurus pratensis further confirm this assumption. BuHL and LANGE (1965) regarded the dead leaves of wild cocksfoot as a significant source of infection; Sprague (1950) and Bollard (1950), among others, suggested that the spores of Mastigosporium are killed on drying. In any case, the author noted a yearly repeated occurrence of the disease, particularly rampant in crops of Dactylis glomerata and Calamagrostis spp., in the same areas and even on the same individual plants. This phenomenon has also been noted elsewhere (Sprague 1938, AustwIaK 1954).

\section{Summary}

Mastigosporium album Riess was found on Alopecurus pratensis $\mathrm{L}$. in various localities ranging from Helsinki to Inari, on $A . g_{\boldsymbol{t}}-$ niculatus L. at Viik (two samples), and on A. arundinaceus Poir. at Hamina (one sample).

M. rubricosum (Dearn. \& Barth.) Nannf. was found on Dactylis glomerata $\mathrm{L}$. in southern and central Finland, on Phleum pratense L., Agrostis tenuis Sibth., and species of Calamagrostis in different localities ranging from Helsinki to Inari. The fungus occurred in samples of C.epigeios (L.) Roth., C. purpurea Trin., and C. arundinaceae (L.) Roth., in southern and central Finland, in C. purpurea, and C.lapponica (Wahlenb.) Hartm. in Inari. The fungus was very rarely found on the leaves of Festuca pratensis Huds., F. fubra L., Lolium perenne L. and Poa pratensis $\mathrm{L}$.

$M$. deschampsiae Jørstad was found on Deschampsia caespitosa L. in Inari.

Artificial inoculation of different grass species with spores of Mastigosporium isolated from the above material resulted in positive infection only in the cases of the grass species that are typical hosts for each fungus.
A resting stage of Mastigosporium resembling cleistothecium, or stroma with inner spores similar to those in leaf flecks was found in the field in several localities ranging from Helsinki to Inari. A resting stage of $M$. album was found on the leaves of Alopecurus pratensis, that of M.rubricosum on dead leaves of Dactylis glomerata, Calamagrostis epigeios, C. purpurea, and C.lapponica during the early spring and summer months. No resting stage has been recorded on Phleum pratense. However the fungus developed spores on leaves of this species early in spring when the foliage was still partly covered with snow.

Viable spores of the fungus were recorded early in spring on all the species of grasses except Calamagrostis spp.

No perfect stage was found for any of the species.

Acknowledgements. - I am thankful to Mrs. Aino Hanhilahti, Agr., Mrs. Eila Metsäpelto, M.Sc., and also to many other persons for their technical assistance, e.g. in collecting and analyzing plant specimens and measuring spores. I am grateful to the University of Helsinki and to my late husband Dr. Aarne Mäkelä for their financial assistance. 


\section{References}

Ainsworth, G. C. 1961: Ainsworth \& Bisby's Dictionary of the fungi. - $547 \mathrm{pp}$. Kew Surrey.

Austwick, P. K. C. 1954: Mastigosporium deschampsiae Jørstad in Great Britain. Trans. Brit. Mycol. Soc. 37: 161-165.

BAudyš, E. 1916: Ein Beitrag zur Kenntnis der Mikromyceten in Böhmen. Lotos 64: 42 -64 .

Bollard, E. G. 1950: Studies on the genus Mastigosporium. I. General account of the species and their host ranges. II. Parasitism. - Trans. Brit. Mycol. Soc. 33: 250-264, $265-275$.

Brummer, V. 1937: Beobachtungen über die in Finnland auf dem Timothee auftretenden Pilzkrankheiten. - J. Sci. Agric. Soc. Finland 9: 165-180.

Buhl, C. \& M. LANGe 1965: Weitere Untersuchungen über das Auftreten von Mastigosporium rubricosum (Dearn. et Barth.) Nannf., dem Erreger einer Blattfleckenkrankheit an Knaulgras, in SchleswigHolstein. - Nachr. B1. Deutschen Pflanzenschultzd., Braunschweig 17: 116-119.

Creelman, D. W. 1956: The unusual occurrence of three leafspotting fungi on grasses in Nova Scotia. - Plant Dis. Rep. 40: 510512.

Frauenstein, K. 1968: Beobachtungen zum Auftreten von Blattfleckenkrankheiten an Futtergräsern. - Nachr. Bl. Deutschen Pflanzenschutzd. Berlin N.F. 22: 4-14.

Hirtonen, J. 1933: Suomen kasvio. - 771 pp. Helsinki.

Hultén, E. 1950: Atlas of the distribution of vascular plants in NW Europe. - 512 pp. Stockholm.

JørstaD, I. 1924: Beretning om plantesydgommer i land og havebruket 1922 - 23. IV. Landbruksvekster og grønnsaker. - $39 \mathrm{pp}$. Kristiania.

- 1945: Parasittsoppene på kultur- og nyttevekster i Norge. I. Sekksporesopper (Ascomycetes) og konidiesopper (Fungi imperfecti). - Meld. Stat. Plante Patol. Inst. 1.-142 pp. Oslo.

- 1947: Coccosporium aucupariae and Mastigosporium deschampsiae, two new Fungi imperfecti. - Forh. Videnskap Selsk. Kristiania 19: 25-28.

KASK, K. 1959: Kõrreliste heintaimede haigustest Tartu ja Jõgeva rajoonis 1956 a. - Eesti Pollumaj. 1: 61-65.
KolkкI, O. 1966: Taulukoita ja karttoja Suomen lämpötiloista kaudelta 1931-1960. Tables and maps of temperature in Finland during 1931-1960. - Suppl. Meteorol. Yearb. Finland 65, 1a: 1-42.

Kornerup, A. \& J. H. Wanscher. 1967: Methuen handbook of color. 2nd ed. - $243 \mathrm{pp}$. London.

LAGey, J. 1967. Mastigosporium leaf fleck of perennial reygrass. - Plant Pathol. 16: 48.

LARsen, P. 1931: Fungi of Iceland. The Botany of Iceland. - 607 pp. København, London.

Lid, J. 1963: Norsk og svensk flora. - 800 pp. Oslo.

Lind, J. 1913: Danish Fungi. As represented in the herbarium of E. Rostrup. - $648 \mathrm{pp}$. Copenhagen.

Lindau, G. 1907: Fungi imperfecti: Hyphomycetes (Erste Häfte) In Rabenhorst KryptogamenFlora von Deutschland, Oesterreich und der Schweiz. I (8). - 852 pp. Leipzig.

Liro, J. I. 1953: Mycotheca Fennica. Die Etiketten No $601-900$ von $H$. Roivainen. Inst. Phytopathol. Univ. Helsingiensis. 102 pp. Helsinki.

Lundell, S. \& J. A. Nannfeldt 1939: Fungi exsiccati Suecici, praesertim upsalienses. Fasc. XVII-XVIII (No 801-900). 41 pp. Uppsala.

Maataloustilastollinen Kuukausikatsaus. Monthly Review of Agricultural Statistics. ElokuuAugust 1969. Maataloushallitus, Tilastotoimisto. Board of Agric. Statist. Off. Helsinki.

PaAtelA, J. 1953: Maamme heinänurmien botaanisesta koostumuksesta. Summary: On the botanical composition of the tamehayfield in Finland. - Acta Agralia Fennica 79 (3) : $1-128$.

Pohjakallio, O. Valkotähäisyyystutkimuksia Jokioisissa kesällä 1935. Referat: Untersuchungen über die Weissährigkeit, Ausgeführt in Jokioinen im Sommer 1935. Valtion Maatalouskoetoiminnan Julkaisuja 77: $1-78$.

Rainio, A. J. 1936: Úber die Dilophospora-Krankheit von Phleum pratense L. und Alopecurus pratensis L. - Valtion Maatalouskoetoiminnan Julkaisuja 87: 1-32.

Ross, J. P. 1954: Mastigosporium album Riess on Alopecurus pratensis in New York. - Plant Dis. Rep. 38: 607-608.

SaCCARDO, P. A. 1886: Sylloge Fungorum IV. 807 pp. Patavii. 
- 1911. Notae mycologicae. - Ann. Mycol. Beriin 9: 249-257.

Sampson, K. \& J. H. Western 1939: Note on a supposed connexion between Mastigosporium album Riess and Dilophospora alopecuri (Fr.) Fr. - Tans. Brit. Mycol. Soc. 22: $168-173$.

- 1942: Diseases of British grasses and herbage legumes. - 85 pp. Cambridge.

Sarv, J. 1960: Mastigosporium sp. sp. esinemine mitmeaastastel kõrrelistel heintaimedel Jõgeva sordia-retusjaamas 1957. — aastal ENSV Põllumajanduse Ministeerium, Teaduslike - Tekn. Inform. Bülletään 4, 1960.

- 1966: Resistentsusaretuse põhiküsimusi Eestis. Eesti maanviljeluse ja maaparanduse teadusliku uurimise instituut. — Teoduslike tööde kogumik 9: 5-26.

Schaffnit, E. \& M. Wieben 1928: Untersuchungen über den Erreger der Federbuschsporenkrankheit Dilophospora alopecuri (Fr.) Fr. - Forsch. Geb. Pflanzenkrankh. Immunität Pflanzenreich 5: 3-38.

Schneider, R. \& J. Meyer 1963: Mastigosporium rubricosum (Dearn. et Barth.) Nannf. als Erreger einer Blattfleckenkrankheit an Futtergräsern in Schleswig-Holstein. - Nachr. Bl. Deutschen Pflanzenschutzd., Braunschweig 15: 81-83.
Sorauer, P. 1874. Handbuch der Pflanzenkrankheiten. - 406 pp. Berlin.

Sprague, R. 1938: Two Mastigosporium leaf spots on Gramineae. - J. agric. Res. 57: 287299.

- 1940: A third species of Mastigosporium on Gramineae. - Mycol. 32: 43-45.

- 1950. Diseases of cereals and grasses in North America. - 538 pp. New York.

Wakefield, E. M. 1918: New and rare british fungi. - R. Bot. Garden Kew, Bull. Misc. Inform. 6: 229-233.

Wenham, H. T. \& G. C. M. Latch 1958: Fungal leaf-spot diseases of Cocksfoot (Dactylis glomerata L.) in the Manawatu. II. Purple leaf-spot caused by Stagonospora maculata (Grove) Sprague, and leaf fleck caused by Mastigosporium rubricosum (Dearn. et Barth. Sprague. - New Zealand. J. Agric. Res. 1: 800-808.

Ylimäkr, A. 1962: The effect of the snow cover on temperature conditions in the soil and overwintering of field crops. - Ann. Agric. Fenniae 1: $92-216$.

Received 23. V. 1970

Printed 21. IX. 1970 